\title{
SEED STUDIES: RED CLOVER WITH SPECTAL REFERENCE TO THE COUNTRY OF ORIGIN OF THE SEED
}

\author{
By R. G. STAPLEDON, M.A. \\ University College of Wales : Aberystwyth. \\ INTRODUCTION
}

THE country of origin of seeds of certain cultivated plants is a question of growing importance, and it is a question which has come into prominence in recent years, owing partly to bad seed harvests at home and to difficulties of transport from abroad. Trials with Red Clover have been conducted on an extensive scale on the Continent. Boerger (2) states that experiments made in Germany, Denmark, Sweden, Norway, Holland and Austria prove beyond discussion that Red Clover does not yield its maximum crop unless locally grown seed is used. Roemer(10) conducted trials in Germany with Red Clover obtained from eighteen different sources; he states that the best results obtained exceeded the worst by one-third of the crop and that seed harvested in East Germany and Central Germany or in countries east of East Germany are the best for use in East Germany. Trials have not been carried out in England on the same scale as on the Continent. Smith(12) at Leeds, however, found that Red Clover obtained from different sources gave very different results for one year leys. He states, for instance, that the greatest weight of hay was obtained from English Single Cut Cowgrass, Canadian, United States and Russian Clovers; whilst amongst those which gave the best stubble grazing in the autumn and spring, after sowing, were Chilian and New Zealand Red Clovers and English Cowgrass, and these were also the clovers which he found stood the winter best. Trials conducted by the writer in Mid-Wales showed that when Chilian Clover succeeded it gave the best stubble grazing; but that at high elevations and on exposed fields it did not stand the winter well. The clovers which stood best into a second year were, moreover, English Single Cut Cowgrass and Red Clovers harvested from the Cotswolds and in Montgomeryshire. Findlay (3) has conducted exhaustive trials in the North of Scotland with clovers of different nationalities, and he finds 
that seed from England or Wales or from the colder northerly regions (e.g. Norway and Sweden) are more reliable than those from southern warmer climates. Trials have also been conducted by the Trade, and the view is very generally held, rightly or wrongly, that Chilian Clover gives excellent results for ordinary one year leys in parts of Scotland, and the Northern ${ }^{1}$ and Eastern Counties of England; but that, generally speaking, good strains of English Clover give the highest yields over the country as a whole, and that for two to three year leys English or Welsh seed is the best and that failing this, of the seed most abundantly on the market that from Brittany and Canada is the most desirable. Piper (9) referring to trials conducted in America quotes results obtained at the Wisconsin Experimental Station in 1901, 1902 and 1905, at the Maine Experimental Station in 1902, and co-operatively by the United States Department of Agriculture in 1905. The highest yjelds were obtained from American (Minnesota, Indiana and Wisconsin) and Orel (Russia) strains. The Orel Clover however yislds but one cutting and consequently the total yield for the whole season would probably not be as great as that of some of the American varieties. With regard to the suitability of American Red Clover for Europe, Piper states that it is objected to on account of its greater hairiness, and that the opinion prevails that the yield is not as a rule as satisfactory and that the plants are more subject to mildew.

Such evidence as is available seems then to indicate that the country of origin of Red Clover seed has a direct influence on the resulting crop; the general superiority of English seed, especially of English Single Cut Cowgrass, is moreover suggested by the fact that good strains of English Clover usually fetch a higher price than foreign seed ${ }^{2}$. It is therefore of considerable importance to be able to recognise the country of origin of a clover sample either by inspection or after subjecting the seed to suitable tests. In the past, the contained weed seeds in a sample have been chiefly relied upon in forming an opinion as to "Country of Origin." This method has been used by Saunders(11) and Stapledon(15) for oat samples, and particulars as to diagnostic weeds met with in samples of grasses and clovers are given by Percival (8) and by Parkinson

1 One reason for Chilian Clover being largely used is, of course, that it is usually cheaper and of better germinating capacity than English; its greater use in Northern Counties being largely due to the fact that the Chilian Dodder is sajd not to become a serious pest in Scotland and the North.

2 It is often said that one reason for the higher price of English seed is the fact that it usually contains greater excess of weed seeds than foreign clover, and therefore costs more to clean. 


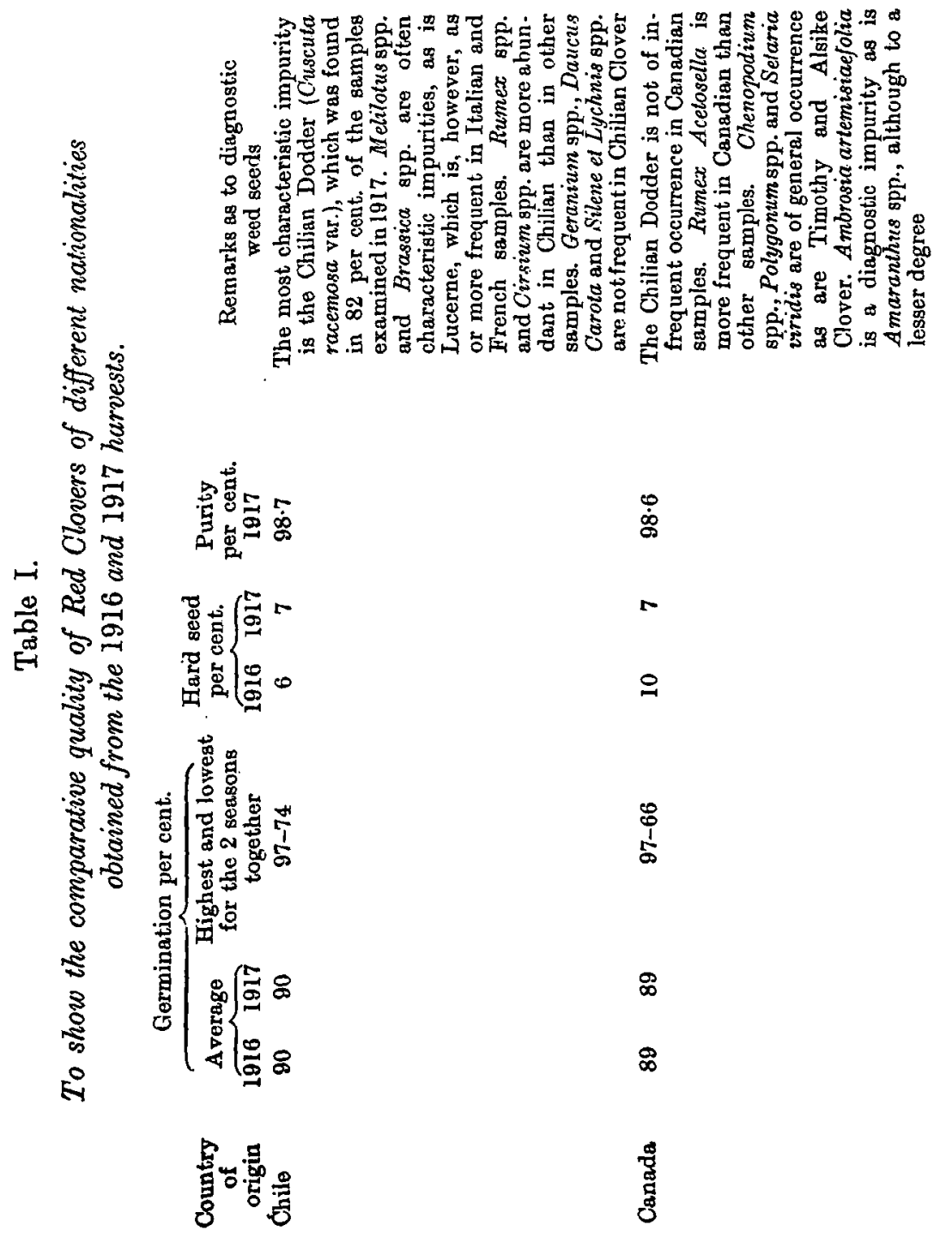



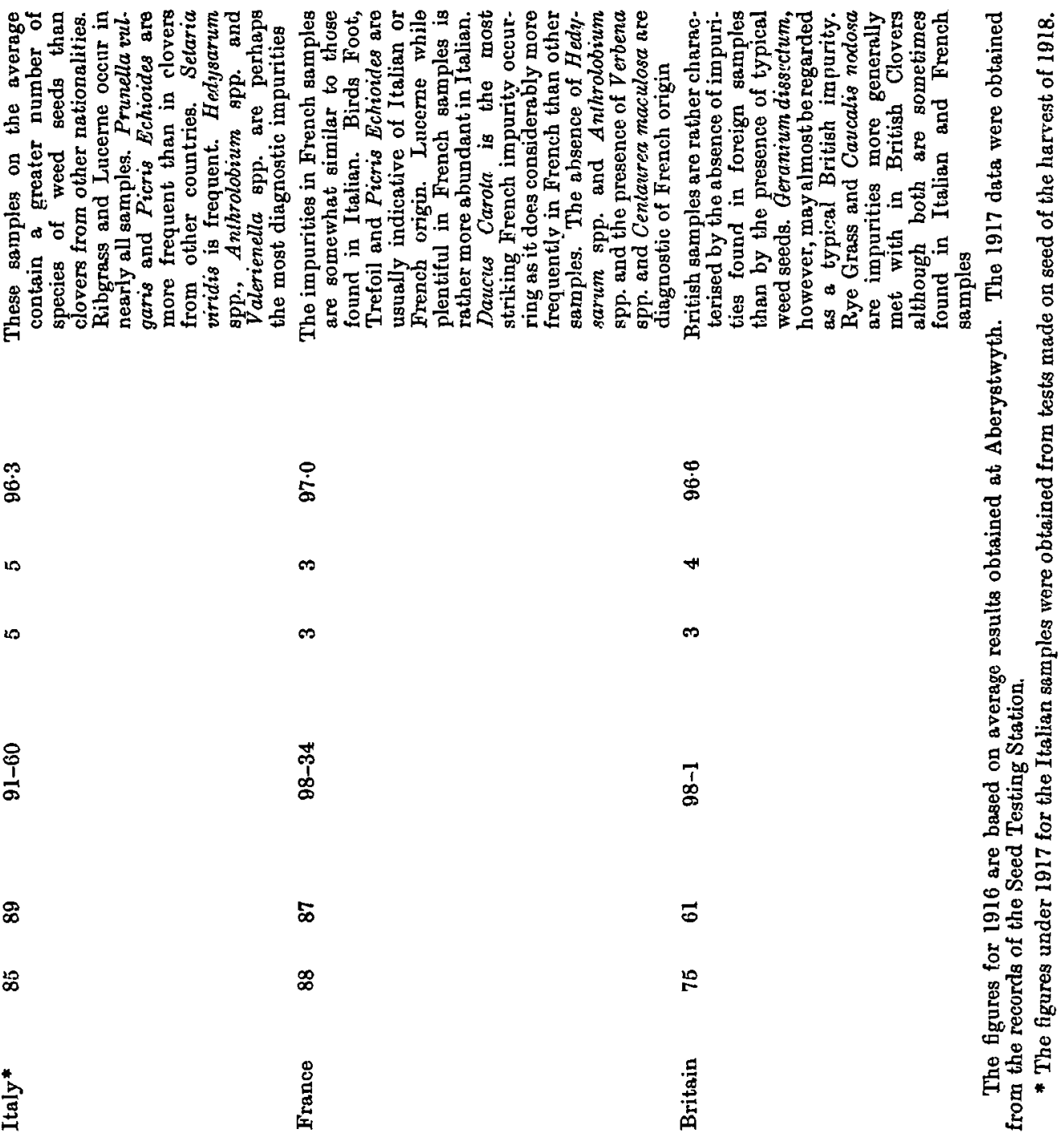

$\stackrel{8}{\circ}$

15

20

$\frac{8}{6}$

$\infty$

$\infty$

$\stackrel{\overrightarrow{5}}{\vec{H}}$ $\stackrel{\varphi}{5}$

$\infty$

$\infty$

盛

$\infty$

$\infty$

蓎 $\stackrel{\circ}{\circ}$

a

6

10

点 
and Smith (7). The "impurity method," however, falls to the ground in the case of well-cleaned samples. The combined result of modern improvements in cleaning machinery and the introduction of the Testing of Seeds Order is, moreover, for cleaner and cleaner samples to be put on the market as time goes on. It was, therefore, decided to start investigations with a view to establishing, if possible, a "country of origin test" other than "impurity" to be applied to Red Clovers.

It is proposed in this article to give an account of the work that has been conducted. It was at first necessary to carry out a number of preliminary tests, and as the enquiry proceeded it was found possible to examine certain phenomena connected with clover seeds in general, but which had no particular relationship to the country of origin of the seed. In order to deal adequately with the subject of this paper it will however be advisable to give a short account of the work as a whole. The major part of the preliminary investigations were conducted by the author at Aberystwyth during 1916 and the beginning of 1917 with samples obtained from the harvests of 1913 to 1916. The work was subsequently continued in greater detail at the Food Production Department's Seed Testing Station with samples obtained from the harvest of 1917 .

\section{GENERAL CHARACTERS OF CLOVER SEEDS OF DIFEERENT NATIONALITIES}

Before describing the detailed investigations which form the subject of this paper, it will serve a useful purpose to indicate the broad differences which occur between the seeds of various nationalities. The comparative qualities of the seeds are shown in Table I.

It will be seen that Chilian and Canadian samples on the average contain the most and French and British the least hard seed. The British samples have a decidedly lower average capacity of germination than the clovers of all the other nationalities considered; Canadian and Chilian samples are consistently better germinaters than either British, French or Italian, for, although the average germinations are not markedly higher than that given by the French and Italian clovers, samples with really poor germinations are much less frequently met with. The Chilian and Canadian samples are also superior in the matter of purity and in this respect the British equally with the Italian are the least satisfactory. With regard to specific impurities, the extent to which the large dodder occurs in Chilian samples is to be noted and this, of course, seriously detracts from the otherwise excellent quality of the 
seed, althongh it must be remembered that this particular dodder, even when sown, does not gain a footing in certain districts. The diagnostic features of the contained weed seeds need not be further discussed but will be referred to in the summary at the end of the paper. The above brief review is unfortunately evidence of the fact that on the average the quality of British seed is less good than that of other nationalities. British seed is therefore, generally speaking, of less attractive appearance. Consequently the farmer who purchases seed solely on its appearance or on the basis of a declaration of purity and germination, without regard to country of origin or strain, runs the grave risk of acquiring an article not well suited to his particular needs.

\section{DETAILED CONSIDERATION OF THE CHARACTERS OF CLOVER SEEDS OF DIFFERENT NATIONALITIES}

Two methods of attack suggested themselves, with a view to recognising the nationality of a sample without having resort to the nature of the weed seeds, namely (1) Careful comparisons of the characters of the seeds, such as size and grain-weight (i.e. weight per 1000 seeds), and the ratio that the seeds of different colours bear to each other in the samples; and (2) The capacity of germination of the samples both at optimum and extreme temperatures, and the germination of the seeds of different colours at different temperatures.

1. The Grain-weight and Colour Characteristics of the Seens.

The chief results obtained under this heading are set out in Table II.

From five to twenty samples were used for arriving at the figures for each country. The British samples were grouped into six grades according to the quality of the seeds and not less than five samples were used to represent each grade. The seeds were graded into three colour classes only, viz. "Yellow," which included lemon-yellow and slightly yellow-ochre seeds, this group consisted of non-mottled and non-parti-coloured seeds; "Violet," which included violet, mauve, mottled and parti-coloured seeds; and "Brown," which included both well-developed and light brown seeds and also such as were shrivelled and poorly developed ${ }^{1}$. It will be convenient to consider the results of the table firstly from a general point of view and secondly from the point of view of the country of origin of the seed.

1 This classification differs from that of Franck and Wierigna (5) who separated their samples into Violet, Mottled, Yellow, Brown (well-developed) and Brown (ill-developed). The simpler classification, however, sufficiently served the purpose of the present investigation. 
Table II.

To show the grain-weight of seeds from different countries, and the grain. weight of seeds of different colours; also the percentage of yellow and brown seeds in the samples.

The average germination of the samples which were used for these tests is also shown.

\begin{tabular}{|c|c|c|c|c|c|c|c|c|}
\hline & & & $\begin{array}{l}\text { Perc } \\
\text { contr }\end{array}$ & $\begin{array}{l}\text { tage } \\
\text { ation }\end{array}$ & We & ht per & 000 seer & in grms. \\
\hline $\begin{array}{l}\text { Couptr } \\
\text { origi }\end{array}$ & & $\begin{array}{l}\text { Average } \\
\text { germina. } \\
\text { tion }\end{array}$ & $\begin{array}{l}\text { of } \\
\text { yellow } \\
\text { seeds }\end{array}$ & $\begin{array}{l}\text { of } \\
\text { brown } \\
\text { seeds }\end{array}$ & $\begin{array}{l}\text { Violet- } \\
\text { cum- } \\
\text { mottled }\end{array}$ & yellow & brown & $\begin{array}{l}\text { All colours } \\
\text { together* }\end{array}$ \\
\hline Chile & 1916 & 90 & 32.9 & $4 \cdot 8$ & $2 \cdot 26$ & $2 \cdot 24$ & $2 \cdot 20$ & $2 \cdot 25$ \\
\hline & 1917 & & $33 \cdot 8$ & $1 \cdot 5$ & $2 \cdot 23$ & $2 \cdot 19$ & $2 \cdot 14$ & $2 \cdot 23$ \\
\hline Italy & 1916 & 85 & $29 \cdot 5$ & $7 \cdot 8$ & $1 \cdot 71$ & $1 \cdot 63$ & $1 \cdot 40$ & 1.69 \\
\hline & 1918 & & $40 \cdot 1$ & $1 \cdot 1$ & 1.74 & 1.68 & $1 \cdot 25$ & 1.70 \\
\hline Canada & 1916 & 89 & $25 \cdot 5$ & $6 \cdot 0$ & $1 \cdot 72$ & 1.54 & $1 \cdot 37$ & 1.65 \\
\hline & 1917 & & 20.7 & $5 \cdot 0$ & $1 \cdot 69$ & $1 \cdot 58$ & 1.40 & 1.62 \\
\hline France & 1916 & 88 & 19.8 & $12 \cdot 8$ & 1.58 & 1.44 & $1 \cdot 28$ & 1.59 \\
\hline & 1917 & & $25 \cdot 4$ & $3 \cdot 6$ & - & - & - & 1.52 \\
\hline British & 1916 & 94 & 13.92 & $15 \cdot 26$ & 2.00 & $1 \cdot 93$ & $1 \cdot 70$ & 2.02 \\
\hline & 1917 & & 12.00 & 34.00 & $2 \cdot 10$ & 1.81 & 1.70 & 2.04 \\
\hline & 1916 & 84 & $15 \cdot 35$ & $17 \cdot 87$ & - & - & - & 2.08 \\
\hline , & 1916 & 76 & 13.40 & $25 \cdot 40$ & - & - & - & 1.94 \\
\hline ," & 1916 & 65 & $9 \cdot 80$ & $25 \cdot 80$ & 1.93 & 1.88 & 1.58 & $1 \cdot 90$ \\
\hline ," & 1916 & 51 & $8 \cdot 30$ & $39 \cdot 80$ & - & - & - & 1.85 \\
\hline$"$ & 1916 & 31 & $4 \cdot 00$ & $31 \cdot 00$ & - & - & - & $l \cdot 73$ \\
\hline
\end{tabular}

The greatest weight per 1000 grain of any Chilian sample was 2.52 grms.

The greatest weight per 1000 grain of any British sample was 2.35 grms.

The greatest amount of yellow seed in any British sample was 24 per cent.

The least amount of yellow seed in any Chilian sample was 23 per cent.

* These weights are the average of a greater number of samples than the weights given for the violet, yellow and brown seeds separately.

\section{(a) General.}

It will be noted that without a single exception the violet-cummottled seeds were heavier than the yellow or the brown, and that the yellow were heavier than the brown. These results confirm those of Franck and Wierigna (5). Birger(1), however, states that yellow and brown seeds do not differ much in weight; this is more or less true in the case of fairly good samples, the brown seed in which is well-developed and not shrivelled, but Franck and Wierigna's figures suggest that even brown seed of this character weighs slightly less than yellow.

A large number of tests were also put up to compare the relative germinations of Yellow, Violet-cum-mottled and Brown seeds. 2200 seeds were used in this connection, the average results were:

Violet-cum-mottled $\quad \ldots \quad \ldots \quad 85$ per cent. germination

$\begin{array}{lllllllll}\text { Yellow } & \ldots & \ldots & \ldots & \ldots & 84 & & & \end{array}$

Brown (largely ill-developed and shrivelled) 
Records were also kept as to the amount of "hard" seed given by the different colours both in connection with the above and other tests. The average results were:

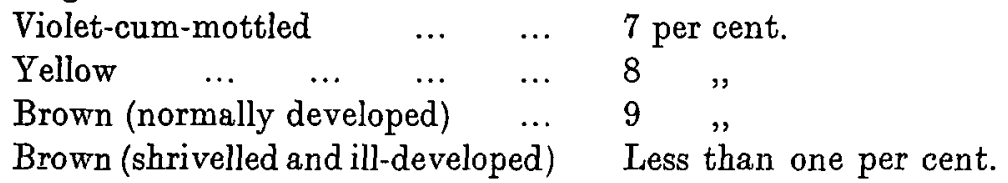

It will be seen from the above figures that there is little or no difference in the germination of Violet-cum-mottled seeds and Yellow seeds, but that the germination of Brown seeds is not nearly as good; the germination of Brown seeds is, moreover, low in proportion to the amount of shrivelled seed present. Samples varied very much with reference to hard seed, in some cases Violet and in other cases Yellow gave the higher percentage- on the average of several thousand seeds, however, Violet, Yellow and Brown (well-developed) did not differ very much; but Brown (ill-developed and shrivelled) seldom gave rise to hard seed. This fact, as Franck and Wierigna (5) point out, should cause no surprise, for as the result of shrivelling, tension of the seed coat occurs which causes small "bursts" and thereby obviates hardness.

If the average germinations are compared to the grain-weight of the seed, it will be seen that no very definite relationship occurs. For instance, Canadian samples with a grain-weight of 1.6 germinated practically as well as Chilian at $2 \cdot 2$, whilst British samples with an average grain-weight of 2.08 did not give as high a germination as those with a grain-weight of $2 \cdot 02$. British samples with low grain-weights and high percentages of brown seed, however, give low germinations. The grain-weight of a group of British samples germinating 31 per cent. was, however, higher than that of a batch of French samples germinating 88 per cent.

The above facts show that it is only legitimate to make direct comparisons between grain-weight and germination when seed from one and the same sample is used and when shrivelled and poorly developed seed is removed. Separations were made on a number of samples and the "heavy" and "light" seed subsequently germinated. Samples of known origin were used, and care was taken not to work with blended samples, in which case the result of sifting might only have been to segregate the component constituents of the blend. The results of these tests are set out in Table III.

The figures indicate that well-developed "heavy" and well-developed "light" seed drawn from the same sample do not differ materially in 
germination ${ }^{1}$. It is interesting to observe, however, that in every case the "light" seed gave rise to a higher percentage of "hard" seed than the "heavy," thus showing that the small and light seed in a sample is more likely to be hard than the larger and heavier seed, and it may be also said that unless "light" seed is shrivelled or undeveloped it will germinate as well as the heavy seed ${ }^{2}$.

Table III.

To show the relative germination capacities of "heavy" and "light" seed separated from the same samples after removing all the ill-developed and shrivelled seed.

$\begin{array}{lccc}\begin{array}{c}\text { Origin of } \\ \text { samples }\end{array} & \begin{array}{c}\text { Weight per } \\ \text { 1000 grain }\end{array} & \begin{array}{c}\text { Germination } \\ \text { per cent. }\end{array} & \begin{array}{c}\text { Hard Seed } \\ \text { per cent. }\end{array} \\ \text { England } & 2 \cdot 40 & 86 & 13.0 \\ & 1.75 & 84 & 16.0 \\ \text { France } & 2.05 & 96 & 1.4 \\ & 1.54 & 96 & 4.0 \\ \text { Chile } & 2 \cdot 40 & 94 & 5.0 \\ & 1.79 & 91 & 8.0 \\ \text { Canada } & 2 \cdot 10 & 93 & 4.8 \\ & 1.64 & 93 & 7.0 \\ \text { Canada } & 2.10 & 91 & 8.0 \\ & 1.57 & 90 & 10.0\end{array}$

Average results:

Grain over 2 grs. per 1000, germination 92 per cent., hard seed 6.4 per cent.

Grain less than 2 grs. per 1000, germination 91 per cent., hard seed 9.0 per cent.

1 Tests of a similar nature had been previously conducted on Oat samples and the results obtained were precisely the same, in some cases the smaller lighter seeds germinated considerably faster than the larger heavy seeds. In the case of Oats, however, the light poorly developed "pinched" seed frequently gave a high percentage of germination.

2 In connection with what has been said above as to the relationship between grain. weight and germination it is of interest to refer to Findlay's (4) work on the size of seed in relation to crop production. He states in summing up his evidence, "That there is no connection between the size of seeds and the produce. True, the largest seeds-the Late Flowering-undoubtedly produce the heaviest crop the first year, but the Broad Leaved English-the smallest seeds-produced the next heaviest. In the second and third years and also on the aggregate the Norwegian-the second smallest seed-produced the heaviest crop, while the Hungarian and medium sized seed gave by far the poorest crop every year." With reference to seeds of different size taken from the same sample, Findlay makes the following observations, "Undoubtedly in many, if not most of our farm seeds, there is a mixture of strains," and in the case of some of his trials it appeared as if the smaller seed represented better and more lasting strains than the large seed. 


\section{(b) The Country of Origin of the Seed 1 .}

The figures in Table II show some interesting differences between the samples representing different countries. It will be noted that the Chilian samples have the highest grain-weight and that English samples come next in weight, but that the heaviest individual English sample was only slightly heavier than the average of all the Chilian samples.

Samples from Canada and Italy bave very similar grain-weights, whilst those from France are the lightest.

The relative amount of yellow and brown seed in the samples in conjunction with the grain-weight of the sample as a whole, however, affords the best guide as to country of origin. The Chilian seeds are remarkable for having a high percentage of yellow seed and an insignificant amount of brown, and consequently, although of very similar grain-weight to some of the best English samples, are generally easily distinguished. The grain-weight of such brown seed as is found in Chilian samples is, moreover, much closer to that of the yellow and violet-cum-mottled seeds than in the case of other nationalities. Seed from Canada cannot be readily distinguished from that from Italy, for the grain-weights and proportions of yellow and brown seeds are very similar although, on the average of two years, the Italian samples would appear to contain the higher proportion of yellow seeds. The seeds of these nationalities, however, differ from Chilian and British in respect of a lower grain-weight, from Chilian on account of a slightly lower proportion of yellow seeds, and from British on account of a considerably lower proportion of brown seeds. The French seed, like the British, would seem to vary more from year to year than that from Chile, Italy and Canada; the low grain-weight appears to be the most constant characteristic. The high proportion of brown seed is the outstanding feature of British samples, and this would seem to differentiate it from the other nationalities considered.

Since the weight of the seed of different nationalities varied and since it was obvious that the difference in weight was correlated with a difference in size, it seemed advisable to conduct experiments with a view to examining the applicability of a "size test:" A number of samples were therefore divided into two grades by passing the seed over

${ }^{1}$ It was not found possible during the War to procure a sufficient number of samples for the purposes of this investigation from countrics other than those recorded in the Table. 
a $1.5 \mathrm{~mm}$. sieve $^{1}$. Tests were subsequently conducted on the two sizes of seeds separately. The results of the sieving tests are given in Table IV.

Table IV.

To show the proportion of seeds retained in and passed by a $1.5 \mathrm{~mm}$, sieve in the case of samples of different nationalities.

\begin{tabular}{lcccccc} 
& \multicolumn{7}{c}{ Percentages by weight of seed. } \\
1.5 mm. sieve & Chilian & British (1) & British (2) & Canadian & French & Italian \\
Seeds retained & $\mathbf{7 3 . 4}$ & 66.6 & 55 & 20.6 & 18 & 20 \\
Seeds passed & $\mathbf{2 6 . 6}$ & $\mathbf{3 3 . 4}$ & 45 & $\mathbf{7 9 . 4}$ & 82 & $\mathbf{8 0}$
\end{tabular}

It will be seen from the above figures that the simple process of sieving (a quicker method than ascertaining grain weights) serves readily to differentiate between British and Chilian samples on the one hand and Canadian, French and Italian on the other.

A sample containing a fair proportion of brown seed was selected from (a) the Canadian samples, $(b)$ the French and $(c)$ the British. Each sample was graded by passing over a $1.5 \mathrm{~mm}$. sieve and the brown and shrivelled seed was then separated from the well-formed and bright seed. The results are shown in Table V.

\section{Table V.}

To show the proportion of bright and well-formed and of dull (brown) and ill-formed seeds retained and passed by a $1.5 \mathrm{~mm}$. sieve in the case of samples of different nationalities.

\begin{tabular}{clccc}
\multicolumn{5}{c}{ Percentages by weight of seed. } \\
1.5 mm. sieve & Character of seed & Canadian & French & British \\
Seeds retained & Well-formed & 23.1 & 32.0 & 53.0 \\
& Brown and shrivelled & 2.3 & 1.5 & 11.0 \\
Seeds passed & Well-formed & 68.3 & 62.3 & 27.0 \\
& Brown and shrivelled & 6.3 & 4.2 & 9.0
\end{tabular}

It will be seen in the case of both the Canadian and French samples that the greater amount of ill-developed seed was amongst the smaller seed, whilst the ill-developed seed was more or less equally distributed between the large and small seed in the British sample.

It has been previously shown that large and small seed taken from a uniform non-blended sample do not differ materially in germination. It seemed probable, however, that sieving a blended sample would be likely to more or less separate the seeds into their component bulks,

1 It was not possible to obtain an absolutely accurate sieve, with a uniform perforation. The same sieve was of course used for all the tests. 
Table VI.

To show the proportion of seeds retained and passed by a $1.5 \mathrm{~mm}$. sieve, and the germination of the large and small seed in the case of samples which consisted of a blend of seeds of two nationalities.

$$
\mathbf{A}=\text { large seed. } \quad \mathbf{B}=\text { small seed. }
$$

(This Table should be considered in conjunction with Table IV.)

\begin{tabular}{|c|c|c|c|c|c|c|c|}
\hline \multirow{2}{*}{\multicolumn{2}{|c|}{ Reference }} & \multirow[b]{2}{*}{ Nationalities } & \multicolumn{2}{|c|}{$\begin{array}{l}\text { Proportions } \\
\text { of seed }\end{array}$} & \multicolumn{2}{|c|}{$\begin{array}{r}\text { Percentage } \\
\text { germination }\end{array}$} & \multirow{2}{*}{$\begin{array}{l}\text { Remarks as to interpretation } \\
\text { of the results }\end{array}$} \\
\hline & & & $\mathrm{A}$ & $\bar{B}$ & $A$ & $\overline{\mathrm{B}}$ & \\
\hline $\mathrm{Aa}$ & 83 & English and French & 67 & 33 & 42 & 37 & $\begin{array}{l}\text { Might have been wholly English, the French } \\
\text { seed probably did not germinate as well as } \\
\text { the English }\end{array}$ \\
\hline Aa & 141 & $"$ & 65 & 35 & 38 & 33 & ditto ditto \\
\hline Aa & 426 & " & 17 & 83 & ธ5 & 70 & $\begin{array}{l}\text { The great majority of the seed was probabl } \\
\text { Frencl }\end{array}$ \\
\hline $\mathrm{Aa}$ & 427 & $\because$ & 19 & 81 & 22 & 47 & ditto \\
\hline Aa & 569 & ", & 34 & 66 & 33 & 62 & $\begin{array}{l}\text { A considerable admixture of French seed } \\
\text { with a higher germination than the English }\end{array}$ \\
\hline Aa & 598 & " & 34 & 66 & 84 & 85 & $\begin{array}{l}\text { A considerable admixture of French seed } \\
\text { with a germination about the same as the } \\
\text { English }\end{array}$ \\
\hline Aa & 614 & " & 36 & 64 & 78 & 88 & $\begin{array}{l}\text { A considerable admixture of French seed } \\
\text { with a germination higher than the English }\end{array}$ \\
\hline$A a$ & 757 & ", & 10 & 90 & 59 & 76 & $\begin{array}{l}\text { The great majority of the seed was probably } \\
\text { French.with a germination bigher than } \\
\text { the English }\end{array}$ \\
\hline $\mathrm{Aa}$ & 784 & $"$ & 47 & 53 & 16 & 19 & $\begin{array}{l}\text { A slight admixture of French seed with a } \\
\text { germination but slightly higher than the } \\
\text { English }\end{array}$ \\
\hline $\mathrm{Aa}$ & 915 & $"$ & 38 & 62 & 47 & 60 & $\begin{array}{l}\text { A moderate admixture of French seed with } \\
\text { a germination decidedly higher than the } \\
\text { English }\end{array}$ \\
\hline $\mathrm{Aa}$ & 945 & ", & 56 & 44 & 77 & 79 & $\begin{array}{l}\text { Nothing to show that the sample was not } \\
\text { wholly English }\end{array}$ \\
\hline $\mathrm{Aa}$ & 1007 & $n$ & 14 & 86 & 62 & 78 & $\begin{array}{l}\text { The great majority of the seed was probably } \\
\text { French }\end{array}$ \\
\hline $\mathrm{Aa}$ & $1] 85$ & " & 44 & 56 & 27 & 55 & $\begin{array}{l}\text { A slight admixture of French seed with a } \\
\text { germination decidedly higher than the } \\
\text { English }\end{array}$ \\
\hline$A \mathrm{~A}$ & 1194 & & 47 & 53 & 13 & 21 & ditto \\
\hline $\mathrm{Aa}$ & 94 & English and Chilian & 56 & 44 & 58 & 65 & $\begin{array}{l}\text { The differences in germination suggest a } \\
\text { blend, but would not bave implied Chilian } \\
\text { and English }\end{array}$ \\
\hline$A a$ & 114 & " & 46 & 54 & 77 & 71 & $\begin{array}{l}\text { The proportions suggest a blend, but would } \\
\text { have implied an admix ture with Canadian } \\
\text { or French seed rather than Chilian }\end{array}$ \\
\hline $\mathrm{Aa}$ & 1008 & , & 28 & 72 & 72 & 40 & $\begin{array}{l}\text { The figures would rather have suggested an } \\
\text { admixture of a little Chilian with a large } \\
\text { amount of poor French or Canadian }\end{array}$ \\
\hline $\mathrm{Aa}$ & 656 & French and Chilian & 28 & 72 & 50 & 60 & $\begin{array}{l}\text { The figures suggest a blend and although } \\
\text { not incompatible with a poor Chilian and } \\
\text { French seed would have suggested English } \\
\text { and French }\end{array}$ \\
\hline $\mathrm{Aa}$ & 205 & $\begin{array}{l}\text { English and } \\
\text { Canadian }\end{array}$ & 38 & 62 & 59 & 69 & $\begin{array}{l}\text { A moderate admixture of Canadian seed with } \\
\text { a better germination than the English }\end{array}$ \\
\hline $\mathrm{Aa}$ & 922 & $\begin{array}{l}\text { English, French, } \\
\text { and Canadian }\end{array}$ & 23 & 77 & 79 & 93 & $\begin{array}{l}\text { A considerable admixture of Canadian and } \\
\text { French seed with a decidedly higher ger- } \\
\text { mination than the British }\end{array}$ \\
\hline
\end{tabular}


and that this would especially be so in the case of blends consisting of large seeds such as British or Chilian with small seeds such as Canadian and French. Thus, if a sample was separated into two sizes and the germination given by the two grades was decidedly different, it would appear reasonable to suppose that such a sample was a blend; if the germinations were practically the same, this would not of course, preclude the possibility of the sample having been blended. Further, if the smaller seeds germinated much better than the larger, this would suggest that French, Italian or Canadian stocks (which usually give higher germinations than British) had been blended with British seed. The comparative germinations of seeds retained and passed by a $1.5 \mathrm{~mm}$. sieve would not, however, be likely to lead to the recugnition of country of origin in a mixture of seeds of nearly equal size such as Canadian and French or of Chilian and British. A consideration of the proportions of seed both passed and retained by a $1.5 \mathrm{~mm}$. sieve (having regard to the proportions that may be expected for samples representing different nationalities) in conjunction with the germination capacities of the siftings might reasonably be expected, however, to help to decide whether a sample was a blend of different nationalities. In order to ascertain whether trials conducted on these lines would be likely to be informing, a number of samples sent to the Seed Testing Station as blends of stated nationalities were tested. The results are given in Table VI.

The facts set out in Table VI and the interpretation put upon the figures show that with but three or four exceptions the tests applied to the samples in question although not being sufficient to give exact, or in some cases even approximate, evidence as to what precise nationalities were involved, none the less would have led to the assumption that the samples were blends.

In order, further, to examine the usefulness of the combined sievinggermination test, it was applied to a number of samples which were sent to the Station "as English" but which owing to their appearance and the contained weed seeds aroused suspicion. The results of these tests are set out in Table VII.

It will be noted that with a single exception (Aa 1241) the sievinggermination test tended to confirm the evidence afforded by the presence, in mere traces, of diagnostic weed seeds. The ratio of large to small seed was furthermore, more or less what would have been expected from an admixture of English with French or Canadian seed. The combined evidence of the weed seeds and sieving-germination tests amount to almost positive proof that the samples under review did not consist wholly of English seed. 


\section{Table VII.}

To show the proportion of seeds retained and passed by $1.5 \mathrm{~mm}$. sieve and the germination of the large and small seed in the case of a number of samples sent to the Station as "English" but which contained impurities diagnostic of foreign origin.

$$
A=\text { large seed. } \quad B=\text { small seed. }
$$

(This Table should be considered in conjunction with Tables IV and VI.)

\begin{tabular}{|c|c|c|c|c|c|c|c|}
\hline \multirow{2}{*}{\multicolumn{2}{|c|}{ Reference }} & \multirow{2}{*}{$\begin{array}{l}\text { Contained weed seeds } \\
\text { suggestive of the foreign } \\
\text { origin of a part at least } \\
\text { of the sample }\end{array}$} & \multicolumn{2}{|c|}{$\begin{array}{l}\text { Proportions } \\
\text { of seed }\end{array}$} & \multicolumn{2}{|c|}{$\begin{array}{l}\text { Percentage } \\
\text { germination }\end{array}$} & \multirow{2}{*}{$\begin{array}{l}\text { Remarks as to the interpretation } \\
\text { of the results }\end{array}$} \\
\hline & & & A & B & A & $\bar{B}$ & \\
\hline $\mathrm{Aa}$ & 11 & $\begin{array}{l}\text { Setaria sp. and Amaranthus } \\
\text { sp. (suggests Canadian } \\
\text { origin) }\end{array}$ & 47 & 53 & 38 & 40 & $\begin{array}{l}\text { Suggests that French, Canadian or } \\
\text { Italian seed of about equal germina- } \\
\text { tion to the English bulk was added. } \\
\text { The weed seeds indicate that the } \\
\text { admix ture consisted of Canadian seed }\end{array}$ \\
\hline$A a$ & 107 & $\begin{array}{l}\text { Verbena sp. (suggests } \\
\text { French origin) }\end{array}$ & 6 & 94 & 72 & 70 & $\begin{array}{l}\text { Suggests that the sample consisted } \\
\text { almost entirely of one of the small- } \\
\text { seeded nationalities - the presence of } \\
\text { Verbena indicating that the seed was } \\
\text { French }\end{array}$ \\
\hline $\mathrm{Aa}$ & 461 & $\begin{array}{l}\text { Centaurea Maculosa } \\
\text { (suggests French origin) }\end{array}$ & 33 & 67 & 54 & 72 & $\begin{array}{l}\text { The figures suggest that a small-seeded } \\
\text { nationality of considerably higher } \\
\text { germination than the English seed } \\
\text { was added in moderate amount. The } \\
\text { contained weed seed implies French } \\
\text { origin }\end{array}$ \\
\hline $\mathrm{Aa}$ & 731 & $\begin{array}{l}\text { Setaria and Lucerne } \\
\text { (suggests French or possi- } \\
\text { bly Chilian origin) }\end{array}$ & 30 & 70 & 41 & 53 & $\begin{array}{l}\text { The figures again indicate the ad- } \\
\text { mixture of a small seeded nationality } \\
\text { of better germination than the Eng. } \\
\text { lish seed, the adulterant was there- } \\
\text { fore probably French seed }\end{array}$ \\
\hline $\mathrm{Aa}$ & 846 & $\begin{array}{l}\text { Setaria and Centaurca ma- } \\
\text { culosa (suggests French } \\
\text { origin) }\end{array}$ & 40 & 60 & 37 & 45 & $\begin{array}{l}\text { A slight admixture of French with } \\
\text { the English seed is suggested by the } \\
\text { weed seeds and is borne out by the } \\
\text { figures }\end{array}$ \\
\hline $\mathrm{Aa}$ & 1090 & $\begin{array}{l}\text { Ambrasia Artemisifolia } \\
\text { and Chilian dodder* } \\
\text { (suggest Canadian origin) }\end{array}$ & 39 & 61 & 73 & 82 & $\begin{array}{l}\text { The figures support the view that a } \\
\text { Canadian seed of higher germination } \\
\text { than the English was used to rein- } \\
\text { force the bulk }\end{array}$ \\
\hline $\mathrm{Aa}$ & 1241 & $\begin{array}{l}\text { Lucerne, Lepidium, cam- } \\
\text { pestre and Daucus Carota } \\
\text { (suggests French and } \\
\text { Canadian origin) }\end{array}$ & 50 & 50 & 90 & 90 & $\begin{array}{l}\text { The figures do not necessarily imply a } \\
\text { blend and are not incompatible with } \\
\text { English seed }\end{array}$ \\
\hline Aa & 1145 & $\begin{array}{l}\text { Birds Foot, Trefoil, Lu- } \\
\text { cerne, Brassica spp., } \\
\text { Chilian and English } \\
\text { Dodder (suggesta Chilian } \\
\text { and French origin) }\end{array}$ & 8 & 92 & 18 & 21 & $\begin{array}{l}\text { The figures suggest that the sample } \\
\text { consisted for the most part of one of } \\
\text { the smaller seeded nationalities, the } \\
\text { impurities indicating French seed. } \\
\text { The presence of Chilian dodder and } \\
\text { Brassica, however, implies a slight } \\
\text { admixture with Chilian seed also }\end{array}$ \\
\hline
\end{tabular}

* Chilian dodder has been frequently found in Canadian samples, consequently it does not follow that Chilian clover was necessarily used as an adulterant in this case. 
The very small amounts of heavy seed in Aa 757 and Aa 1007 (Table VI) and in Aa 1145 (Table VII) suggest that the majority of these samples consisted of siftings or cleanings. It has, therefore, to be borne in mind, in this connection, that a blend of large and small seed of the same nationality could not be distinguished from a blend of different nationalities by the sieving-germination test alone.

The data brought forward in this section show, however, that by an adroit use of the grain-weight, colour ratio, and sieving-germination tests, it is possible to form some opinion as to the country of origin of a sample and in certain cases as to the component nationalities of a blend.

It will be shown hereafter that differential germination tests afford further evidence, and in the summary at the end of the paper an endeavour will be made to indicate a scheme of testing that will help towards the recognition of blended samples as such and the nationality of the clovers so blended.

\section{Germination Tests conducted at Optimum and Extreme Temperatures.}

It will be convenient to deal with the work carried out in this connection under two sub-headings as before, i.e. (a) General, and (b) As it bears upon the country of origin of the seed.

\section{(a) General.}

It seemed probable that germination tests conducted at different temperatures might reveal facts concerning the quality of seeds not shown by tests conducted at optimum temperatures, also that the rapidity of germination at different temperatures might prove of significance, and that the results so obtained might be influenced by the country of origin of the seeds.

Nearly 200 samples of seeds were used in conducting the necessary tests and over 1200 germination tests (3-6 sets of 100 seeds each) were made. The seeds were germinated in closed Hearson Incubators at $20^{\circ} \mathrm{C}$., $25^{\circ} \mathrm{C}$., $30^{\circ} \mathrm{C}$., $35^{\circ} \mathrm{C}$. and $40^{\circ} \mathrm{C}$. At Aberystwyth the sets were put up in petri dishes, with a seed bed of two moist filter papers and covered with a single moist paper ${ }^{1}$. The moisture was kept as uniform as possible (e.g. about 60 per cent. saturation) throughout the test by spraying as necessary. At the Seed Testing Station, the sets were put up on glass

14 -in. petri dishes were used and an initial uniformity of moisture was assured by using 5 c.c. of water per each petri in the first instance. 


\section{Table VIII.}

To show average germinations of samples of different grades and ages at different temperatures; the top figures are the actual germinations and the bottom figures the percentage loss of germination below that at $20^{\circ} \mathrm{C}$.

Samples tested from current (1916) harvest.

$\begin{array}{cccccc}\text { Character of samples } & 20^{\circ} \mathrm{C} . & 25^{\circ} \mathrm{C} . & 30^{\circ} \mathrm{C} . & 35^{\circ} \mathrm{C} . & 40^{\circ} \mathrm{C} . \\ \text { Grade 1 } & 87 & 87 & 84 & 77 & 60 \\ 97 \text { samples } & & 0 & 3.4 & 11 \cdot 4 & 31 \cdot 0 \\ \text { Grade 2 } & 73 & 68 & 62 & 58 & 22 \\ 30 \text { samples } & & 6.8 & 15 \cdot 0 & 20.5 & 70 \cdot 0 \\ \text { Grade 3 } & 46 & 43 & 31 & 30 & 9 \\ 15 \text { samples } & & 6 \cdot 6 & 32 \cdot 6 & 34.8 & 80 \cdot 4 \\ \text { Grade 4 } & 31 & 26 & 21 & 16 & 2 \\ 3 \text { samples } & & 16 \cdot 0 & 32 \cdot 2 & 48.3 & 93.5\end{array}$

\section{Samples of different ages.}

13 samples
Original germination
$92 \%$

2 samples

Original germination $97 \%$

Original germination $94 \%$

(a) Yearling $=1$ year old.

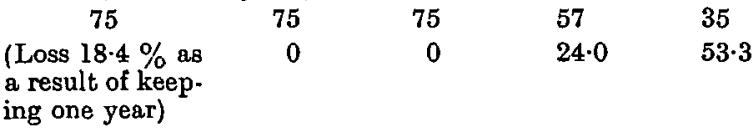

(b) Two years old.

\begin{tabular}{lcrll}
\multicolumn{1}{c}{76} & 74 & 76 & 67 & 26 \\
(Loss 21.6\% as a & $2 \cdot 6$ & 0 & $11 \cdot 8$ & $65 \cdot 8$ \\
result of keeping & & & & \\
two years) & & & &
\end{tabular}

(c) Three years old.

$\begin{array}{lcllc}48 & 40 & 21 & 16 & 3 \\ \begin{array}{l}\text { (Loss 48.9 \% as a } \\ \text { result of keeping }\end{array} & 8 \cdot 5 & 56 \cdot 2 & 66 \cdot 6 & 93 \cdot 7 \\ \text { three years) } & & & & \end{array}$

(d) Four years old.

15 samples
Original germination
$96 \%$

10 samples

Original germination $66 \%$

26

26
(Loss $72.9 \%$ as a
result of keeping

16

$38 \cdot 4$

four years)

$$
8
$$

4

$50 \cdot 0$

(Loss 88.0\% as a result of keeping four years)

(e) Five years old.

\section{1 sample}

Original germination $97 \%$
1

$87 \cdot 5$

(Loss 91.7\% as a

result of keeping five years)

$\begin{array}{lll}10 & 7 & 3\end{array}$

$\begin{array}{lll}61.5 & 73.0 & 88.4\end{array}$

$42 \quad 2 \quad 0$

$\begin{array}{lll}50 \cdot 0 & 75 \cdot 0 & 100\end{array}$

$$
\text { tive years) }
$$


plates standing on petri dishes containing water, the filter papers on the glass plates being kept moist by wicks. This latter proved much the best plan for the purpose required since uniformity of moisture in all cases was assured.

The preliminary germination tests were conducted wholly at Aberystwyth. with seeds of obviously different qualities. Samples of different ages, which had accumulated in the writer's laboratory at Aberystwyth, and those representing different grades of the 1916 harvest were first tested at different temperatures, no regard being paid to the country of origin of the seeds. The average results of these preliminary tests are set out in Tables VIII and IX.

Table IX.

To show the percentage number of samples of grades 1, 2 and 3 (see Table VIII) which germinated best at the several temperatures.

\begin{tabular}{|c|c|c|c|c|c|}
\hline \multirow{3}{*}{$\begin{array}{c}\text { Character of samples } \\
\text { Grade l } \\
\text { Average germination } \\
\text { at } 20^{\circ} \text { C. }=87 \%\end{array}$} & \multicolumn{5}{|c|}{ Germination at } \\
\hline & $20^{\circ} \mathrm{C}$. & $25^{\circ} \mathrm{C}$. & $30^{\circ} \mathrm{C}$ & $35^{\circ} \mathrm{C}$ & $40^{\circ} \mathrm{C}$ \\
\hline & $53 \%$ & $25 \%$ & $12 \%$ & $\begin{array}{l}4 \% \text { germinated } \\
\text { as well as at } \\
\text { lower tempera. } \\
\text { tures }\end{array}$ & $\begin{array}{l}\text { None germinated } \\
\text { as well as at } \\
\text { lower tempera- } \\
\text { tures }\end{array}$ \\
\hline $\begin{array}{c}\text { Grade 2 } \\
\text { Average germination } \\
\text { at } 20^{\circ} \mathrm{C}=73 \%\end{array}$ & $66 \%$ & $23 \%$ & $2 \%$ & None & ditto \\
\hline $\begin{array}{l}\text { Grade } 3 \\
\text { Average germination } \\
\text { at } 20^{\circ} \mathrm{C} .=46 \%\end{array}$ & $55 \%$ & $20 \%$ & $0.5 \%$ & None & ditto \\
\hline
\end{tabular}

The figures show that the better quality samples resist the bigher temperatures much better than the inferior grades. In the case of all grades, however, the average figures show a considerable falling off at $35^{\circ} \mathrm{C}$. and a greater falling off still at $40^{\circ} \mathrm{C}$. Inferior samples frequently, however, are unable to resist $35^{\circ} \mathrm{C}$. and (or) even $30^{\circ} \mathrm{C}$. as well as good samples can $40^{\circ} \mathrm{C}$. When individual samples are considered and not average figures (vide Table IX) it will be seen that the optimum temperature for germination of Red Clovers cannot be expressed as a single temperature but varies for individual samples from a temperature probably about $20^{\circ}$ to as high as $30^{\circ} \mathrm{C}$., but that the majority of samples may be expected to germinate best at a little above $20^{\circ} \mathrm{C}$. Thus the usual temperature employed for testing clovers, i.e. $22^{\circ} \mathrm{C}$., is probably the best single and uniform temperature to use as favouring the majority of the samples tested, but will by no means give the best results for an appreciable proportion of the samples. 
In the case of really good samples the difference between the germinations obtained at $20^{\circ} \mathrm{C}, 25^{\circ} \mathrm{C}$. or even $30^{\circ} \mathrm{C}$. seldom amounts to more than 5 per cent. In the case of poor samples, however, the difference between the results obtained at $20^{\circ} \mathrm{C}$. and $25^{\circ} \mathrm{C}$. may in a few instances amount to 10 or 12 per cent. and although the higher figure in the case of these big discrepancies is generally obtained at $20^{\circ} \mathrm{C}$, in about 12 per cent. of such cases it occurred at $25^{\circ} \mathrm{C}$.

If grades 3 and 4 (from a current harvest, see Table VIII) are compared respectively with samples three and four years old having very similar germinations, it will be noted that the old seeds show a greater falling off in germination at $25^{\circ} \mathrm{C}$, and a very much greater falling off at $30^{\circ} \mathrm{C}$. and $35^{\circ} \mathrm{C}$. than do the seeds from a current harvest whose poor germination must have been due solely to adverse conditions at harvesting ${ }^{1}$. A comparison of the results obtained for yearling and two year old samples with grade 2 samples from a current harvest of about similar germination, if anything, show in favour of the older samples. It would thus seem that if originally good samples are well stored very pronounced deterioration need not take place until the third year and that the behaviour of samples at $30^{\circ} \mathrm{C}$. and $35^{\circ} \mathrm{C}$. in comparison with their germinations at $20^{\circ} \mathrm{C}$. affords some indication as to whether inferior germination is due to a sample being three or more years old or to the fact that the seed matured and (or) was harvested under adverse conditions.

It is evident from the above consideration of the facts that the behaviour of a sample at temperatures above the optimum has a definite bearing on the quality of the seed. It may be of interest, therefore, to compare the energy of germination of a few samples with their germinations at different temperatures. Ten samples were grouped in pairs, each pair having practically similar germinations, in some cases the energy was also similar, in others it was decidedly different. The results of the tests are given in Table $\mathrm{X}$.

It will be seen that in groups (3), (4) and (5) where the energy of germination was higher in one sample than the other, the degree of resistance to higher temperatures was greater in the case of the sample with the best energy of germination. In groups (1) and (2) where the energy was practically the same in the case of both samples in each group, the resistance to high temperatures was much greater in G 16 than G 11 and in F 16 than F10. It would therefore appear that

.1 The loss of germination at $40^{\circ} \mathrm{C}$. is so great in the case of both old and poorly harvested seed that a comparison of results at this temperature is without significance. 
germination tests conducted at extreme temperatures would afford a more certain index of vigour than the energy of germination at optimum temperatures ${ }^{1}$. It will be shown in the next section, however, that the results of energy and differential temperature tests are open to misinterpretation and should only be used as a guide to excellence when comparing samples of the same strain and from the same country of origin $^{2}$.

\section{Table X.}

To contrast the energy of germination of samples with their behaviour at different temperatures.

\begin{tabular}{cccccccc} 
& & & \multicolumn{5}{c}{ Germination at } \\
\cline { 3 - 7 } Samples & $\begin{array}{c}\text { Energy of germination } \\
\left(=3 \text { days at } 20^{\circ} \mathrm{C}\right)\end{array}$ & $20^{\circ} \mathrm{C}$. & $25^{\circ} \mathrm{C}$. & $30^{\circ} \mathrm{C}$. & $35^{\circ} \mathrm{C}$. & $40^{\circ} \mathrm{C}$. \\
(1) G 16 & 71 & 82 & 75 & 75 & 75 & 55 \\
& G 11 & 71 & 82 & 80 & 71 & 60 & 11 \\
(2) & F 16 & 54 & 79 & 82 & 71 & 68 & 53 \\
& F 10 & 57 & 78 & 78 & 63 & 50 & 22 \\
(3) G 43 & 41 & 55 & 53 & 46 & 40 & 20 \\
& G 18 & 22 & 56 & 48 & 24 & 29 & 20 \\
(4) & E 2 & 45 & 54 & 61 & 54 & 48 & 28 \\
B 1 & 36 & 55 & 53 & 50 & 52 & 10 \\
(5) & B 2 & 40 & 50 & 50 & 50 & 48 & 10 \\
& D 3 & 24 & 50 & 40 & 26 & 23 & 2
\end{tabular}

It will be convenient to consider the question of hard seed and the behaviour of seeds of different colours at different temperatures in conjunction with the nationality tests described in the next section.

\section{(b) The Country of Origin of the Seed.}

Without REFERENCE TO THE COLOUR OF THE SEED OR TO HARD SEED.

Samples representing the various nationalities were tested at different temperatures; the average results are set out in Table XI.

It will be noted that the germinations reached in 20 hours were in all cases less when tested by the method adopted at the Seed Testing Station (i.e. on filter papers kept moist by wicks) than when tested under drier conditions on moist filter papers not served by wicks ${ }^{3}$.

\footnotetext{
1 That resistance to high temperatures affords an index of vigour is, of course, implied by the results given in Table VIII.

${ }^{2}$ It was intended to grow a number of the samples tested in nursery lines in order to compare growth with the germination tests here described. Owing to the writer leaving Aberystwyth early in 1917 it was unfortunately impossible to do so.

3 Tests at the Seed Testing Station have proved that the "wick" method tends to maintain too wet a seed-bed for red clovers especially in the case of samples of poor quality; these seeds are now tested on filter papers resting upon moist sand.
} 
Table XI.

To show the germination of samples representing different nutionalities at different temperatures. The upper figures are the Aberystwyth (1916 harvest) results and the lower the Seed Testing Station (1917 harvest) results. The figures in brackets represent the percentage decrease in germination below that given in 10 days at $20^{\circ} \mathrm{C}$.

The figures directly below each nationality indicate the number of samples upon which the Aberystwyth averages were based. The Seed Testing Station results were obtained on bulks made up of a large number of samples.

\begin{tabular}{|c|c|c|c|c|c|c|c|c|c|c|}
\hline \multirow[b]{3}{*}{$\begin{array}{l}\text { Country of } \\
\text { origin }\end{array}$} & \multicolumn{10}{|c|}{ Percentage germination at } \\
\hline & \multicolumn{2}{|c|}{$20^{\circ} \mathrm{C}$} & \multicolumn{2}{|c|}{$25^{\circ} \mathrm{C}$} & \multicolumn{2}{|c|}{$30^{\circ} \mathrm{C}$. } & \multicolumn{2}{|c|}{$35^{\circ} \mathrm{C}$. } & \multicolumn{2}{|c|}{$40^{\circ} \mathrm{C}}$. \\
\hline & $\begin{array}{l}\text { in } 20 \\
\text { hrs. }\end{array}$ & $\begin{array}{c}\text { in } 240 \\
\text { hrs. }\end{array}$ & $\begin{array}{l}\text { in } 20 \\
\text { hrs. }\end{array}$ & $\begin{array}{c}\text { in } 240 \\
\mathrm{hrs} .\end{array}$ & $\begin{array}{l}\text { in } 20 \\
\text { hrs. }\end{array}$ & $\begin{array}{l}\text { in } 240 \\
\text { hrs. }\end{array}$ & $\begin{array}{l}\text { in } 20 \\
\text { hrs. }\end{array}$ & $\begin{array}{l}\text { in } 240 \\
\text { hrs. }\end{array}$ & $\begin{array}{l}\text { in } 20 \\
\text { hrs. }\end{array}$ & $\begin{array}{c}\text { in } 240 \\
\mathrm{hrs} .\end{array}$ \\
\hline \multirow[t]{2}{*}{$\begin{array}{l}\text { Chile } \\
(30)\end{array}$} & 70 & 90 & 80 & 90 & s1 & 91 & 68 & $\begin{array}{c}87 \\
(3 \cdot 3)\end{array}$ & 36 & $\begin{array}{c}71 \\
(21 \cdot 1)\end{array}$ \\
\hline & 3 & 95 & 42 & 95 & 61 & 95 & 12 & $\begin{array}{c}89 \\
(6-3)\end{array}$ & 20 & $\begin{array}{c}73 \\
(23 \cdot 0)\end{array}$ \\
\hline $\begin{array}{c}\text { Italy* } \\
(9)\end{array}$ & 66 & 85 & 69 & 86 & 70 & $\begin{array}{c}82 \\
(3 \cdot 5)\end{array}$ & 55 & $\begin{array}{c}72 \\
(15 \cdot 5)\end{array}$ & 33 & $\begin{array}{c}54 \\
(36 \cdot 4)\end{array}$ \\
\hline \multirow[t]{2}{*}{$\begin{array}{l}\text { Canada } \\
\text { (12) }\end{array}$} & 36 & 89 & 42 & $\begin{array}{c}86 \\
(3 \cdot 3)\end{array}$ & 42 & $\begin{array}{c}83 \\
(7 \cdot 0)\end{array}$ & 40 & $\begin{array}{c}77 \\
(13 \cdot 3)\end{array}$ & 20 & $\begin{array}{c}64 \\
(28 \cdot 0)\end{array}$ \\
\hline & 8 & 89 & 4 & 91 & 7 & $\begin{array}{c}88 \\
(1 \cdot 1)\end{array}$ & 1 & $\begin{array}{c}63 \\
(29 \cdot 41)\end{array}$ & 12 & $\begin{array}{c}73 \\
(18 \cdot 0)\end{array}$ \\
\hline \multirow[t]{2}{*}{$\begin{array}{l}\text { France } \\
\quad(6)\end{array}$} & 64 & 88 & 78 & 88 & 76 & 88 & 63 & $\begin{array}{c}86 \\
(2 \cdot 2)\end{array}$ & 13 & $\begin{array}{c}60 \\
(31 \cdot 7)\end{array}$ \\
\hline & 5 & 93 & 46 & 95 & 59 & 94 & 7 & $\begin{array}{c}90 \\
(3 \cdot 2)\end{array}$ & 11 & $\begin{array}{c}72 \\
(22 \cdot 5)\end{array}$ \\
\hline \multirow[t]{2}{*}{$\begin{array}{c}\text { Britain } \dagger \\
(46)\end{array}$} & 27 & 86 & 52 & $\begin{array}{c}84 \\
(2 \cdot 3)\end{array}$ & 43 & $\begin{array}{c}77 \\
(10 \cdot 4)\end{array}$ & 30 & $\begin{array}{c}71 \\
(17 \cdot 4)\end{array}$ & 9 & $\begin{array}{c}50 \\
(41.8)\end{array}$ \\
\hline & 3 & 80 & 20 & 80 & 23 & 81 & 3 & $\begin{array}{c}63 \\
(21 \cdot 2)\end{array}$ & 0 & $\begin{array}{c}41 \\
(61 \cdot 2)\end{array}$ \\
\hline
\end{tabular}

* An insufficient number of Italian samples were received at the Seed Testing Station in the season 1917-18 to conduct these tests.

t Only the results obtained on good British samples are included in this Table, in order to compare germinations as near as possible to those of the foreign clovers.

The final germinations obtained by the two methods are, however, seen to be sufficiently comparable. In some respects the seeds of all nationalities behave in a similar manner; for instance the rate of germination with but one minor exception was greater at $25^{\circ} \mathrm{C}$. than at $20^{\circ} \mathrm{C}$, and no very appreciable difference was to be seen between the rates at $25^{\circ} \mathrm{C}$. and $30^{\circ} \mathrm{C}$. At $35^{\circ} \mathrm{C}$., however, germination began to be much slower even in the case of samples which reached nearly as high final figures as at $20^{\circ} \mathrm{C}$. or $25^{\circ} \mathrm{C}$. It will be noted also, that the final germina- 
tions at $35^{\circ} \mathrm{C}$. were lower than those at $30^{\circ} \mathrm{C}$. and that with but one exception (Canada) the final results at $40^{\circ} \mathrm{C}$. were very considerably lower than those at $35^{\circ} \mathrm{C}$. (cf. Table VIII). The irregular behaviour given by the Canadian sample tested at the Seed Testing Station must, almost certainly, have been due to an error or an accident; the temperature of the $40^{\circ} \mathrm{C}$. incubator may have dropped or that of the $35^{\circ} \mathrm{C}$. incubator advanced during some period of the test. The results given in the Table show very marked contrasts between the British and foreign samples. Speaking generally, the foreign samples germinated faster than the British at all temperatures, but $25^{\circ} \mathrm{C}$. gave the least well marked contrast in this respect. The final germinations at $35^{\circ} \mathrm{C}$. showed a greater proportional falling off in the case of the British than all other samples (except the Canada result which is suspect) whilst at $40^{\circ} \mathrm{C}$. the proportional drop was even greater, being on the average over twice as considerable for the British as the Chilian samples.

The figures show that the behaviour of the different foreign samples under review is not sufficiently varied to distinguish one nationality from another by the results given at different temperatures. It would seem, however, that the Chilian samples tend to be the fastest germinators at all temperatures and tend also on the average of seasons to do proportionately better at $40^{\circ} \mathrm{C}$. than the French, Canadian or Italian samples. It is unfortunate that the relatively small seeded Canadian, Italian and French samples cannot be differentiated by resort to the tests described; it would; however, appear as if the French and Canadian seed withstand high incubation temperatures rather better than the Italian.

Although the results can clearly not be used to identify the actual nationality of any particular sample, they are of decided interest and undoubtedly afford a useful addition to methods previously discussed to aid in differentiating between home grown and foreign clovers. In particular the contrast between the behaviour of Chilian and British samples is so great as to have very considerable practical application.

It may therefore be interesting to give some further comparative details relative to the tests conducted on these samples. A comparison of the number of British and Chilian samples germinating hest at the different temperatures is made in Table XII and the average rates of germination of six typical Chilian samples and eight typical British samples are shown in detail in Table XIII.

The tables are self-explanatory and do not demand comment. It is, however, of special interest to note that Chilian clovers may begin to 
germinate at $30^{\circ} \mathrm{C}$. (if the seed bed is not too wet) after no more than eight hours, and will practically complete their germination in three days, and have an exceedingly high energy of germination (i.e. germination in three days) at $20^{\circ} \mathrm{C}$. A high rapidity of germination (i.e. germination in 20 hours) with a high energy of germination would always be sufficient to render a "British" sample suspect, thus it is unfortunate that emphasis is often laid on the value of the "energy" test without any reservations being made in the direction of explaining that the energy of germination of British samples is usually low compared to foreign.

Table XII.

To show the percentage number of Chilian and British samples (Aberystwyth results) which germinated best at the different temperatures.

\begin{tabular}{|c|c|c|c|c|c|}
\hline Nationality & At $20^{\circ} \mathrm{C}$ & At $25^{\circ} \mathrm{C}$ & At $30^{\circ} \mathrm{C}$. & At $35^{\circ} \mathrm{C}$ & At $40^{\circ} \mathrm{C}$. \\
\hline Chile & 30 & 27 & 27 & $\begin{array}{l}\text { None best but } \\
27 \text { as well as } \\
\text { at lower tem. } \\
\text { peratures }\end{array}$ & None \\
\hline Britain & $\begin{array}{l}87 \text { best or } \\
\text { equally as } \\
\text { good }\end{array}$ & 15 & $\begin{array}{l}\stackrel{2}{14} \text { did } \\
\text { equally } \\
\text { well }\end{array}$ & $\begin{array}{l}\text { None best but } \\
5 \text { as well as } \\
\text { at lower tem- } \\
\text { peratures }\end{array}$ & None \\
\hline
\end{tabular}

Table XIII.

To compare the rapidity, energy and final germinations of typical Chilian and British Clovers at certain temperatures.

\begin{tabular}{|c|c|c|c|c|c|c|c|c|c|c|c|c|}
\hline \multirow[b]{2}{*}{ Nationality } & \multicolumn{4}{|c|}{ At $20^{\circ} \mathrm{C}$. } & \multicolumn{5}{|c|}{ At $30^{\circ} \mathrm{C}}$. & \multicolumn{3}{|c|}{ At $40^{\circ} \mathrm{C}$. } \\
\hline & $\begin{array}{c}12 \\
\mathrm{hrs} .\end{array}$ & $\begin{array}{c}20 \\
\text { hrs. }\end{array}$ & $\begin{array}{c}3 \\
\text { days }\end{array}$ & $\begin{array}{c}10 \\
\text { days }\end{array}$ & $\begin{array}{c}8 \\
\mathrm{hrs}\end{array}$ & $\begin{array}{c}12 \\
\text { hrs. }\end{array}$ & $\begin{array}{c}20 \\
\text { hrs. }\end{array}$ & $\begin{array}{c}3 \\
\text { days }\end{array}$ & $\begin{array}{l}10 \\
\text { days }\end{array}$ & $\begin{array}{c}12 \\
\text { hrs. }\end{array}$ & $\begin{array}{c}20 \\
\text { hrs. }\end{array}$ & $\begin{array}{c}10 \\
\text { days }\end{array}$ \\
\hline Chile & 32 & 70 & 88 & 92 & 5 & 60 & 81 & 91 & 93 & 11 & 40 & 72 \\
\hline Britain & 8 & 53 & 75 & 86 & 0 & 32 & 53 & 73 & 77 & 0 & 9 & 50 \\
\hline
\end{tabular}

The results given in Tables XI and XII suggest that it would not be necessary to put up germination tests at $20^{\circ} \mathrm{C} ., 25^{\circ} \mathrm{C}, 30^{\circ} \mathrm{C}, 35^{\circ} \mathrm{C}$. and $40^{\circ} \mathrm{C}$. on any sample that was suspect. The best plan to follow in the case of samples giving a high rapidity of germination at $20^{\circ} \mathrm{C}$. would be to put up an additional test at $35^{\circ} \mathrm{C}$. taking care not to have a sodden seed bed and let this additional test run for 20 hours. If something like 50-60 per cent. of the seeds germinating in 10 days at $20^{\circ} \mathrm{C}$. germinated in 20 hours at $35^{\circ} \mathrm{C}$. this would render the sample in question more than ever suspect and exhaustive tests on the lines suggested in the summary should then be undertaken. 
It was pointed out in an earlier section that by separating a sample into seeds of two sizes and germinating the seeds separately, it was possible to obtain an indication as to whether a sample was a blend. It would now appear that if the seeds in one separation although of equal germinating capacity to those in the other were more resistant to incubation at higher temperatures, this would afford additional evidence.

A number of tests were therefore conducted on large and small seeds extracted from single unblended samples, and these were germinated separately at $20^{\circ} \mathrm{C}$. and $40^{\circ} \mathrm{C}$.; it was found in many instances that large and small seeds as such did not behave differently at the two temperatures but that on the average the small seed appeared to be slightly more resistant to incubation at $40^{\circ} \mathrm{C}$. than the large, differences in excess of 5 per cent. were, however, the exception.

Thus when differences of the order of 8 to 10 per cent. in the power of resistance to incubation at $40^{\circ} \mathrm{C}$. are met with, the implication is that foreign seed has been used in the blend. If reference is made to Table VI giving the results of the combined sieving-germination test it will be noted that $\mathrm{Aa}$ 83, Aa 141 and Aa 945 were designated blends of English and French, but that the sieving-germination test would not alone have been sufficient to recognise this fact, a comparison of the germinating capacities at $20^{\circ} \mathrm{C}$. and $40^{\circ} \mathrm{C}$., however, affords the necessary clue, for the smaller (presumably chiefly French) seed proved to be 8 per cent. more resistant at $40^{\circ} \mathrm{C}$. than the larger in the case of $\mathrm{Aa} 83 ; 11$ per cent. in the case of Aa 141 and 20 per cent. in the case of Aa 945; and this notwithstanding the fact that the germination of both large and small seed were practically the same at $20^{\circ} \mathrm{C}$. It is only necessary to add that in 18 cases out of 28 tested by both the sieving-germination method and at $20^{\circ} \mathrm{C}$. and $40^{\circ} \mathrm{C}$. a comparison of the results at the higher and lower temperature tended to further confirm the fact that the samples were, as stated, blends of English with either French or Canadian seed. It is not so easy to identify blends of English and Chilian clover by the sieving method and subsequent germination of the separations at $20^{\circ} \mathrm{C}$. and $40^{\circ} \mathrm{C}$. because the seeds on both sides of the sieve are frequently too similar to the original blend. It is also difficult to detect the component nationalities of a blend in the case of many yearling or older samples when the germination of all the seed is low and the power of resistance of all the seed to incubation at $35^{\circ} \mathrm{C}$. and $40^{\circ} \mathrm{C}$. is also poor. 


\section{WITH REFERENCE TO THE COLOUR OF THE SEED.}

The average results obtained in respect of the seeds of different colours at different temperatures for the various nationalities are given in Table XIV.

Table XIV.

To show the germination of the seeds of different colours at different temperatures for various nationalities.

\begin{tabular}{|c|c|c|c|c|c|c|c|c|c|}
\hline \multirow[t]{2}{*}{ Nationality } & \multicolumn{3}{|c|}{$\begin{array}{l}\text { Yellow } \\
\text { at }\end{array}$} & \multicolumn{3}{|c|}{$\begin{array}{c}\text { Violet-cum-mottled } \\
\text { at }\end{array}$} & \multicolumn{3}{|c|}{$\begin{array}{c}\text { Brown } \\
\text { at }\end{array}$} \\
\hline & $20^{\circ} \mathrm{C}$. & $30^{\circ} \mathrm{C}$ & $\overline{40^{\circ}} \mathrm{C}$. & $20^{\circ} \mathrm{C}$. & $30^{\circ} \mathrm{C}$ & $40^{\circ} \mathrm{C}$. & $20^{\circ} \mathrm{C}$. & $30^{\circ} \mathrm{C}$ & $40^{\circ} \mathrm{C}$ \\
\hline Chilian & 88 & 92 & 76 & 83 & 85 & 64 & 70 & 60 & 3 \\
\hline British & 81 & 80 & 48 & 83 & 76 & 38 & (a) 39 & 39 & 7 \\
\hline & & & & & & & (b) 12 & 14 & 1 \\
\hline French & 82 & 81 & 73 & 88 & 91 & 41 & 72 & 60 & 5 \\
\hline Canadian & 77 & 74 & 70 & $\$ 4$ & 91 & 65 & & & \\
\hline Italian & 85 & 72 & 54 & 92 & 87 & 65 & & & \\
\hline Average figures & S4 & 82 & 63 & 85 & S4 & 55 & & & \\
\hline
\end{tabular}

(a) More or less well formed brown seeds.

(b) Shrivelled and ill-developed brown seeds.

It will be sedn that with the exception of the Italian (where the violet were slightly more resistant than the yellow) the yellow seeds are a little more resistant to incubation at $40^{\circ} \mathrm{C}$. than are the violet-cum-mottled. Individual samples of ail nationalities, however, give violet seeds more resistant than yellow, so that it is probable that the nationality of the seed does not influence the comparative resistance as between yellow and violet seeds, but that on the average, yellow seed is slightly more resistant than violet. This is what might be expected in view of the fact that speaking generally it is those nationalities which contain the most yellow seed that give the highest germinations at $40^{\circ} \mathrm{C}$. The figures in the table show that brown seed of all nationalities is far less resistant to incubation at $40^{\circ} \mathrm{C}$. than yellow or violet, and that ill-formed and shrivelled brown seed is hardly capable of germination at $40^{\circ} \mathrm{C}$. The poor germination of British samples at $40^{\circ} \mathrm{C}$. is therefore largely due to the considerable amounts of brown seed they usually contain. That the poor resistance of the brown seed is not alone sufficient to account for the difference between British and foreign samples is, however, evident from consideration of the figures in the table, for yellow and violet British seeds are seen to be less resistant than yellow and violet Chilian, French or Canadian seeds. 


\section{WITH REFERENCE TO HARD SEED.}

The amount of hard seed in samples did not on the average vary very much when the seed was incubated at different constant temperatures, but in most samples tended to be rather less at $40^{\circ} \mathrm{C}$. and in some cases less at $35^{\circ} \mathrm{C}$. than at lower temperatures. The results obtained on selected samples containing high percentages of hard seed are set out in Table XV.

\section{Table XV.}

To show the effect of Incubation at different constant temperatures on the amount of hard seed.

\begin{tabular}{ccccccc}
\multicolumn{6}{c}{} & \multicolumn{6}{c}{ Percentage of hard seed. } \\
\cline { 2 - 7 } Canadian & J 2 & 22 & 25 & 27 & 25 & 16 \\
& J 6 & 14 & 7 & 10 & 8 & - \\
& J 9 & 21 & 16 & 24 & 15 & - \\
& J 10 & 11 & 12 & 12 & 10 & - \\
Italian & K 6 & 14 & 27 & 12 & 15 & - \\
Chilian & A 8 & 12 & 12 & 11 & 14 & 15 \\
& A 12 & - & 14 & 9 & 6 & 10 \\
& A 26 & 11 & 2 & 7 & 6 & 1 \\
English & D 2 & 42 & 42 & - & 33 & 20
\end{tabular}

It will be noted that the greatest decrease occurred in the case of the English sample D 2 which contained only half as much hard seed when incubated at $40^{\circ} \mathrm{C}$. as at $20^{\circ} \mathrm{C}$. It would appear, therefore, that hardness is a matter of degree and that much of the hard seed in D 2 was not as "hard" as that contained in the Chilian sample A 8 , for example. That hardness is a matter of degree is further shown by the fact that "hard" seed when incubated for long periods will continue to germinate slowly. The hard seed was collected from a number of Chilian samples after the ordinary test of 10 days at $20^{\circ} \mathrm{C}$. and incubated for a further 18 days at different temperatures with the following results:

At $22^{\circ} \mathrm{C}$. gave 15 per cent. germination and 86 per cent. hard.

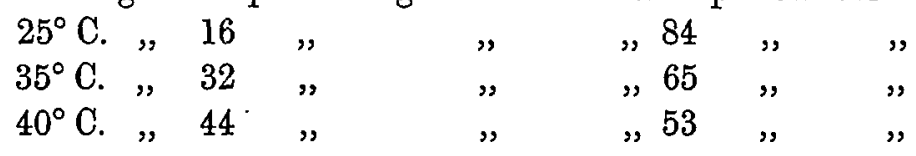

The above figures go to show that temperatures at and above $35^{\circ} \mathrm{C}$. are less favourable to hardness than lower temperatures and tend to confirm Harrington's $(6)$ view that the selection of any particular constant temperature from $1^{\circ} \mathrm{C}$. to $30^{\circ} \mathrm{C}$. has little effect upon the softening of impermeable clover seeds. 
There was no evidence to show that hard seed from clovers of different nationalities beha ved very differently at different temperatures, or that hard yellow, violet-cum-mottled or brown seed behaved in any way differently the one from the other at different temperatures. Consequently the behaviour of hard seed is of little or no diagnostic significance in relation to nationality tests. A number of tests were conducted to ascertain whether a fluctuating temperature between $20^{\circ} \mathrm{C}$. and $40^{\circ} \mathrm{C}$. would obviate hardness, and it was found that no very appreciable results were obtained. This confirmed Harrington's (6) experiments, for he found that alternations of temperature have but little effect if none of the temperatures used fall below $20^{\circ} \mathrm{C}$. He found, however, when a temperature of $10^{\circ} \mathrm{C}$. or cooler is used in alternation with a temperature of $20^{\circ} \mathrm{C}$. or warmer that many hard seeds germinate and that the effect of such an alternation of temperature is greatly increased by previously exposing the seeds to germination conditions at a temperature of $10^{\circ} \mathrm{C}$. or cooler ${ }^{1}$.

\section{SUMMARY AND CONCLUSIONS.}

(1) Current literature has been cited to support the view that the country of origin of Red Clover has a very important bearing on the suitability of the seed for crop production in any particular locality; it is therefore a matter that should be considered of just as much and

${ }^{1}$ It is of interest to give a brief account of Harrington's conclusions relative to the use of "hard" (=impermeable) seeds. The value to the farmer of hard seed will vary according to the kind of seed, the germinating capacity, the percentage of hard seed, the age (in samples several years old the "hard" seed may be of more value than the rest of the bulk) and time of sowing of the seed. If the amount of hard seed is not considerable, say less than 10 per cent., and if the rest of the "lot" consists of strong germinable seed the "hard" seeds are of little importance, both because of their fewness compared to the seeds that will germinate readily and because of the varying sowings per acre according to common practice. "Hard" clover seed sowed early in the spring is of more value than the same seed sown later; when sown early in the spring a month or so before the end of freezing wenther, the chances are that the majority of the hard seed will germinate; when sown after the freezing period but a month or so before the end of the cool weather about two-thirds of the seed may be expected to germinate, but when sown late in the spring or in the summer probably only about one-tenth of the hard seed will germinate.

It may be added that in this country (Harrington's investigations were conducted in America) clovers are usually sown in April, May or June, that is to say, more or less after the freezing period and thus hard seed is of considerable significance, especially in the case of Red Clover sown for an ordinary one year ley. It is probably of less significance in the case of White Clover sown for 2-4 year leys and for Late Flowering red clover sown for leys of similar duration, for if the seed does not germinate during the spring in time to contribute to the first year's herbage it is likely to germinate after the freezing period of the following winter and early spring and will contribute to the herbage of subsequent years. 
perhaps more importance, than germination and purity. There seems to be little doubt but that, generally speaking, locally grown seed or at least seed harvested in countries no warmer or but little warmer than the district where the seed is to be sown, is likely to produce plants which will "stand" the longest and in many instances produce the heaviest hay crops in the first year after sowing.

(2) Investigations were therefore undertaken with a view to establishing a "Nationality test" for Red Clovers. It is only legitimate to draw provisional conclusions from the results brought forward in this paper. It was only possible to experiment with comparatively few nationalities, and to deal exhaustively with two seasons' harvests ${ }^{1}$. The tests described, however, proved to be informing and seem to indicate that the seed of certain groups of nationalities can be more or less distinguished from that of other groups.

(3) The work described had an important bearing on the quality of red clover seeds in general, and in many of its phases was complementary to investigations undertaken by other writers.

The following statement which applies equally to clovers of all nationalities would appear to be justified by the investigations undertaken and (or) by the works referred to in the body of the paper.

(a) The violet, mauve and mottled seeds, are heavier than the yellow, and both are heavier than the brown seeds in a sample.

(b) There is little or no difference in the germinating capacity between the violet-cum-mottled seeds and the yellow; but both of these germinate better than the brown. Well-formed and plump brown seeds germinate better than ill-formed and shrivelled brown seeds, but even the former do not germinate as well as violet and yellow.

(c) Yellow seeds are slightly more resistant to incubation at $40^{\circ} \mathrm{C}$. than are violet-cum-mottled and at optimum temperatures frequently germinate rather more quickly. Brown seeds (well-developed) are considerably less resistant to incubation at $40^{\circ} \mathrm{C}$. than violet or yellow; whilst brown seeds (ill-developed) are almost incapable of germination at $40^{\circ} \mathrm{C}$.

(d) The amount of "hard" seed found amongst yellow, violetcum-mottled and brown (well-formed) seeds although often markedly different in individual samples does not on the average vary very much, but is probably least among the violet. Brown (ill-formed) seeds do not, however, give rise to an appreciable amount of hard seed.

(e) Incubation at single constant temperatures above the optimum

1 It is evident also that samples of the same nationality must vary considerably amongst themselves according to the particular district in which they were grown. 
up to $35^{\circ} \mathrm{C}$. does not on the average decrease the amount of hard seed, but at $40^{\circ} \mathrm{C}$. the amount of hard seed is usually somewhat less. Individual samples are, however, met with which give very appreciably less hard seed at $30^{\circ} \mathrm{C}$. and $35^{\circ} \mathrm{C}$. than at $20^{\circ} \mathrm{C}$. or $25^{\circ} \mathrm{C}$. This suggests that "hardness" is a matter of degree. That this is so is borne out by the fact that "hard" seed will continue to germinate slowly when incubated for a period of months.

Incubation at a fluctuating temperature of $20^{\circ} \mathrm{C}$. to $40^{\circ} \mathrm{C}$. did not on the average much hasten the germination of hard seed. In this connection the conclusions of Harrington(6) were cited; namely, that "Alternations of temperature cause the softening and germination of many impermeable clover seeds when a temperature of $10^{\circ} \mathrm{C}$. or cooler is used in alternation with a temperature of $20^{\circ} \mathrm{C}$. or warmer."

It would appear also that incubation with a constantly over-saturated seed bed does not obviate hardness, but evidence in connection with routine seed testing suggests that by slightly fluctuating the moisture content of the seed bed the amount of "hard" seed may in some cases be slightly reduced. The small seed taken from a sample usually gives a slightly higher percentage of "hard" seed than does the large.

$(f)$ Small and light seed, if well developed, does not, as such, differ in germination from large and heavy seed. The small seed extracted from a pure sample (representing an unblended bulk) will usually germinate as well as the large and is often slightly more resistant to incubation at $40^{\circ} \mathrm{C}$. than the large.

(g) Samples vary very much in their power of resistance to incubation at temperatures above the optimum (about $20^{\circ}$ C. $-22^{\circ}$ C.). Samples in good condition and of high germinating capacity being altogether more resistant than those in poor condition and of low germination. Samples three or more years old (although originally excellent) appear to be less resistant to incubation at $35^{\circ} \mathrm{C}$. and $40^{\circ} \mathrm{C}$. than do those from a current harvest with a poor capacity of germination due to adverse weather conditions.

(h) The degree of resistance to incubation at high temperatures is probably a better index of vigour than energy of germination-samples with practically similar energies of germination may exhibit very different degrees of resistance to incubation at $35^{\circ} \mathrm{C}$. and $40^{\circ} \mathrm{C}$. As a general rule, however, those samples which germinate most rapidly at $20^{\circ} \mathrm{C}$. will also attain to the highest germinations at $35^{\circ} \mathrm{C}$. and $40^{\circ} \mathrm{C}$.

4. It is possible as a result of the work undertaken to draw up a scheme for conducting a critical nationality test on any particular sample of red clover. It has been shown that Chilian, Canadian, French 
and Italian clovers all tend to have bigher rapidities and energies of germination and to be more resistant to incubation at high temperatures than British. A good energy result therefore, although denoting vigour, may also imply at least admixture with a foreign clover; and therefore may afford reason for refusing rather than accepting a sample. It is just these attractive looking samples which give high energies of germination that should be subjected to the nationality test described hereunder.

(a) Examine not less that 2 oz. of the sample with a view to making a complete list of all the weed and other seeds present (if any). This should be done by passing the whole sample over the "Dodder Machine." The presence or absence of diagnostic weed seeds, and the combination of weed seeds, will afford some evidence, but not necessarily conclusive evidence. Excess of the iarge Chilian dodder, in a large seeded sample, with a high proportion of yellow seeds would suggest a Chilian clover, a few seeds of the Chilian dodder in a smaller seeded sample would be compatible with Canadian seed. Chilian dodder, however, in small traces may be met with in seed harvested in this country ${ }^{1}$.

(b) Ascertain the grain-weight of the seeds, and the proportion of yellow to brown seeds. This will aid in the differentiation between Chilian and English samples on the one hand, both being of high or relatively high grain-weight, the former having a high percentage of yellow and the latter of brown seed. French, Italian and Canadian seeds on the other hand will have lower grain-weights. The above tests will not necessarily be sufficient to detect a blend of two nationalities and should be supplemented as follows:

(c) Separate the sample into two grades "large," and "small," by passing over a $1.5 \mathrm{~mm}$. sieve. Ascertain the proportion of brown to yellow seeds for each grade separately. Germinate each grade separately both at $20^{\circ} \mathrm{C}$. and at $40^{\circ} \mathrm{C}$. If the proportion of "large" to "small" seed is very different to the average of British samples it is not unlikely that the sample consists of a blend, although the blend may be the result of bulking the cleanings (= small seed) from one English "lot" with another un-cleaned or only partially cleaned "lot." If the proportion of yellow seeds is considerably higher in the case of small seeds than the large, it would be legitimate to suspect that the small seed consisted largely of (1) Italian, (2) Canadian, or (3) French seed. The separation of English from Chilian seed is not so complete by sieving, but a considerably higher proportion of yellow seed amongst the large

I The writer has found a few seeds of Chilian dodder in a sample of Red Clover harvested in Montgomeryshire. 
seed would be confirmatory evidence of the presence of Chilian seed. If the germination of the large and small seed was decidedly different, it would be highly probable that the sample was a blended one, although not necessarily of different nationalities. If, however, the small seed proved to be considerably more resistant to incubation at $40^{\circ} \mathrm{C}$. than the large, the implication would be that the sample consisted of a greater or less amount of Canadian, Italian or French seed. Consequently, if such a sample gave a higher proportion of yellow amongst the small seed than amongst, the large and if weed seeds diagnostic of Canada, France or Italy were also found, it would be almost certain that one of these nationalities contributed to the bulk.

(d) It would therefore appear that it is often possible to detect a blended sample, and in many cases also to form a very shrewd opinion as to what nationalities contributed to the bulk. It must be emphasised, however, that no one test-comparable to a chemical test-can be applied to clover seeds which would give absolute evidence as to country of origin. The tests described, however, afford strong circumstantial evidence, and should always be applied to samples of a suspicious character offered for sale as "English." There is not the leaist doubt that a very appreciable amount of "English" clover has been in the past adulterated with that of foreign origin ${ }^{1}$, and even if a few genuine English samples were to be rejected by purchasers on the results given by a critical nationality test-the gain would be enormous if farmers would refuse delivery of "English" seed which in the opinion of a competent analyst was suspect as to place of origin.

My thanks are due to my former colleagues at the Seed Testing Station for valuable help in connection with that part of the work conducted in London. I am, in particular, indebted to Miss M. Adams, B.Sc., who was responsible for all the tests carried out in reference to grading the samples on a size basis, and for numerous tests conducted at different temperatures. I owe it to the energy of Miss Adams and of Miss Hopkin that it was possible to conduct all the necessary tests during the comparatively short time available for investigational work of this character.

1 Chilian dodder was found in 30 samples of Red Clover purporting to be of English origin during season 1917-18 at the Food Production Department's Seed Testing Station, and a large number of samples contained weed seeds snggestive of foreign origin (16). Over 50 per cent. of the Red Clover samples examined by the present writer in 1913 contained weed seeds suggestive of the foreign origin of a part at least of the samples containing thom (13). In 1915 a sample of Red Clover offered for sale as Welsh was tested by the author at Alicrystwyth; it was of a suspicious appearance, and eventually seeds of Chilian dodder were found in the $3 \mathrm{lb}$. bulk. It was returned to the vendor by the purchaser (14). 
My thanks are also due to a number of Seed Firms who kindly sent me samples of different nationalities to Aberystwyth, and especially to Mr H. H. Dunn, of Bournemouth and Salisbury, who, at considerable pains, procured for me a large number of genuine English-grown samples from different counties. I am equally indebted to Mr Dymond, Seed Analyst, Department of Agriculture, Ottawa, who kindly sent me samples of Red Clover from Canada, and to Messrs Burton and Oldershaw who were good enough to procure samples from Somerset and the Eastern Counties respectively, and to Mr Flattely, who kindly forwarded me samples from Italy.

\section{REFERENCES TO LITERATURE.}

(1) Birger, Kajends. "On the Germination Energy of Red Clover Seed." See Abstracts of Papers in Bull. of Agricultural Intel. Rome, Year III, No. 3, March, 1912.

(2) Bonrger, Albert. "The Question of the Locality from which Clover and other Meadow Grass Seeds are Exported." See Alistracts of Papers, ibid. Year III, No. 5, May, 1912.

(3) Innday, Wy. M. "Red Clover." Bulletin No. 24 of The North of Scotland College of Agriculture.

(4) _ "The Size of Seed." Bulletin No. 23 of The North of Scotland College of Agriculture.

(5) Franck, W. J., and Wieringa, J. "Laden van de meest voorkomende Klaverachtige gewassen." Verslagen van Landbounlundige Onderzockingen der Rykslandbnunproefstations, No. 21.

(6) Harrington, George T. "Agricultural Value of Impermeable Seeds." Journal of Agricultural Research, 6, No. 20, August, 1916.

(7) Parkinson, S. T. and Shrth, G. "Impurities in Agricultural Seed." Headley Brothers.

(8) Percival, Prof. J. Collection of Weed Seeds. University College, Reading.

(9) Prper, Charles V. Forage Plants and their Culture. 1917.

(10) Rokmer, C. "Cultural Experiments in Germany with Trifolium Pratense." See Abstracts of Papers in Bull. of Agricultural Intel. Rome. Year VII, No. 2. February, 1916.

(11) SaUnders, C. B. "The Identification of the Country of Origin of Commercial Oat Samples." Royal Agricultural College, Cirencester. Scientific Bulls. Nos. 4 and 5, 1912-13.

(12) Simrt, W. G. "Report on Nationalities and Varieties of Red Clover." Bulletin No. 57, 1906. The University of Leeds.

(13) Stapledon, R. G. The Condition of the Seed Trade in the Aberystwyth College Area. Aberystwyth, 1914.

(14) - Report on Seeds purchased in Central and South Wales. Seasons 1915-16. The Journal of the Board of Agriculture, 23, No. 9, December, 1916.

(15) _ "Identification of the Country of Origin of Conmercial Oats." Ibid. 23, No. 2, May, 1916.

(16) First Annual Report. The Official Seed Testing Station at the Food Production Department. Ibid. 25, No. 6, September, 1918. 